\title{
Biodiesel Production from Palm Methyl Ester (PME) -Review
}

\author{
Aasif Procha ${ }^{1}$, Rakesh Kumar ${ }^{2 *}$, Santosh $\mathrm{Kumar}^{3}$, Radhe Sham ${ }^{4}$, Anmol Singh Brar ${ }^{5}$ \\ 1,4,5) B.Tech. Students, 2, 3) Assistant Professor, Department of Mechanical Engineering, \\ Chandigarh Group of Colleges, Landran, Mohali, Punjab, India.
}

\begin{abstract}
In the era of the increase in globalization, this led to increase in industrialization and motorization. It's obvious that with the increase in motorization the consumptions of auto fuels had been increased since long. This may lead to a reduction of fuels (diesel \& petrol). Also, environmental issues have arisen from the emissions of toxic pollutants and greenhouse gases. Hence, it is necessary to look for an alternate energy source to respond this problem. To overcome this problem the replacer of fuel in CI engines had been introduced, i.e. "biodiesel". Biodiesel is composed of fatty acid and some vegetable oils. This review paper briefly describes different biodiesel production methods, especially the production of biodiesel using palm methyl ester (PME) oil, by transesterification process. In addition, it also compares the yield of biodiesel produced form mill effluents and palm oil by-products using flask and batch reactor.
\end{abstract}

Keywords - Biodiesel, transesterification, PME, Reactor, mill effluent.

\section{INTRODUCTION}

Energy is the main element for the economic development of the nation. Due to rapidly increasing demands of energy supply of fossil fuel sources such as coal, petroleum and natural gas leads to boost the cost, environmental degradation and minimize security [1]. Currently, India imported approx. 2/3rd of its petroleum requirements every year, which occurred a cost nearly Rs. 81,000 crores in foreign exchange. Although, even five percent replacement of diesel and petrol based fuel by biodiesel can help India to save Rs. 4000 crores every year in foreign exchange. Hence biodiesel is an alternate renewable source for long period energy security. Biodiesel has many advantages like non toxic, inexhaustible, high cetane no., biodegradable, clean burning, ecofriendly, reduce harmful emissions $\left(\mathrm{HC}, \mathrm{CO}, \mathrm{NO}_{\mathrm{X}}\right)$ and have low sulphur content [2-5]. There are ample of sources from where biodiesel can be produced i.e. from soybean oil, coconut oil, palm oil, sunflower oil, cotton seed oil, etc. However, due to low volatility, large molecular mass, and more kinematic viscosity of vegetable and animal oils it cannot directly use in the engine. [6]. Hence, to solve these issues, different methods have been used for the production of biodiesel namely blending with petro-diesel, pyrolysis, micro emulsification and transesterification.

\subsection{Blending (mixing)}

Fuel can be prepared for functioning of the engine by the process of blending or mixing, in which the diesel fuel is directly mixed with preheated vegetable oil or animal oil. When a blend of $95 \%$ of filtered used cooking oil and $5 \%$ of diesel was prepared, the process was experimentally carried out which gave a positive result while used in diesel engine [7]. Some of major problem faced during blending was regarding the high fuel viscosity, low volatility, poor atomization and incomplete fuel combustion [8]. Hence some other methods were introduced to overcome these problems.

\subsection{Micro-emulsification}

It is an ideal method for biodiesel production that overcome the problem of the high viscosity of fuel in which the vegetable or animal oils were solubilised in a solvent (alcohol) and surfactant until the desired viscosity was achieved. Some commonly used solvent during this process are methanol $\left(\mathrm{CHO}_{3} \mathrm{OH}\right)$, ethanol $\left(\mathrm{C}_{2} \mathrm{H}_{5} \mathrm{OH}\right)$ and butanol $\left(\mathrm{C}_{4} \mathrm{H}_{9} \mathrm{O}\right)[9]$. 


\subsection{Pyrolysis (thermal cracking)}

The process in which the vegetable or animal oils is preheated and decomposed at high temperature $\left(>350^{\circ} \mathrm{C}\right)$ is known as pyrolysis. This method is effective, eco friendly and not requiring washing, drying or filtering. But it has some limitations such as it produce low purity of biodiesel, costly equipment and need high temperature. Pyrolysis of vegetable oil became a major course for investigators to be studied for the production of fuel product [10].

\subsection{Transesterification}

Transesterification is a process where triglycerides changed to diglycerides then diglycerides are transformed to monoglycerides, subsequently monoglycerides changed to esters and glycerol as represented in Figure 1. This process has high conversion with relatively low cost. The commonly used catalyst to boost the rate of chemical reactions during tansesterification process includes sodium hydroxide $(\mathrm{NaOH})$, potassium hydroxide $(\mathrm{KOH})$, and sodium methoxide $\left(\mathrm{CH}_{3} \mathrm{NaO}\right)$ [11].

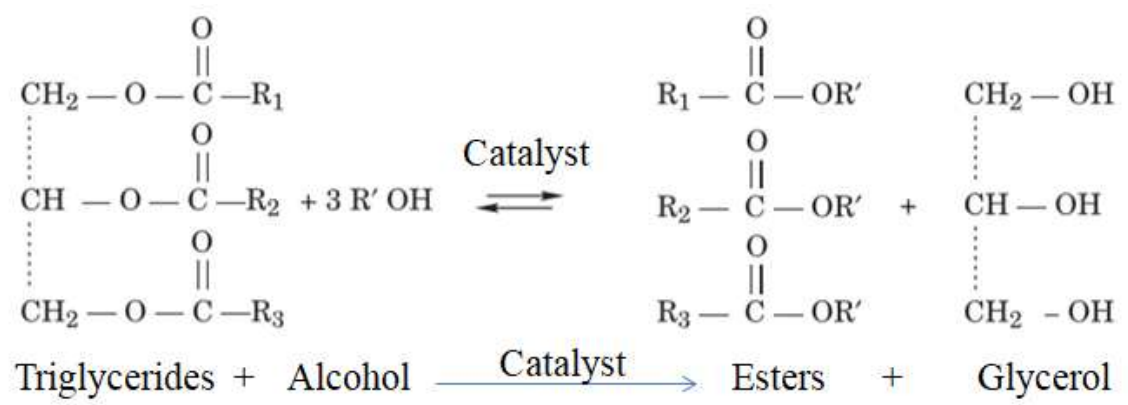

Figure 1: Transesterification reactions

\section{BIODIESEL PRODUCTION FROM PALM OIL BY TRANSESTERIFICATION METHOD.} in Figure 2.

The steps involved during biodiesel production from palm oil by transesterification reaction are shown

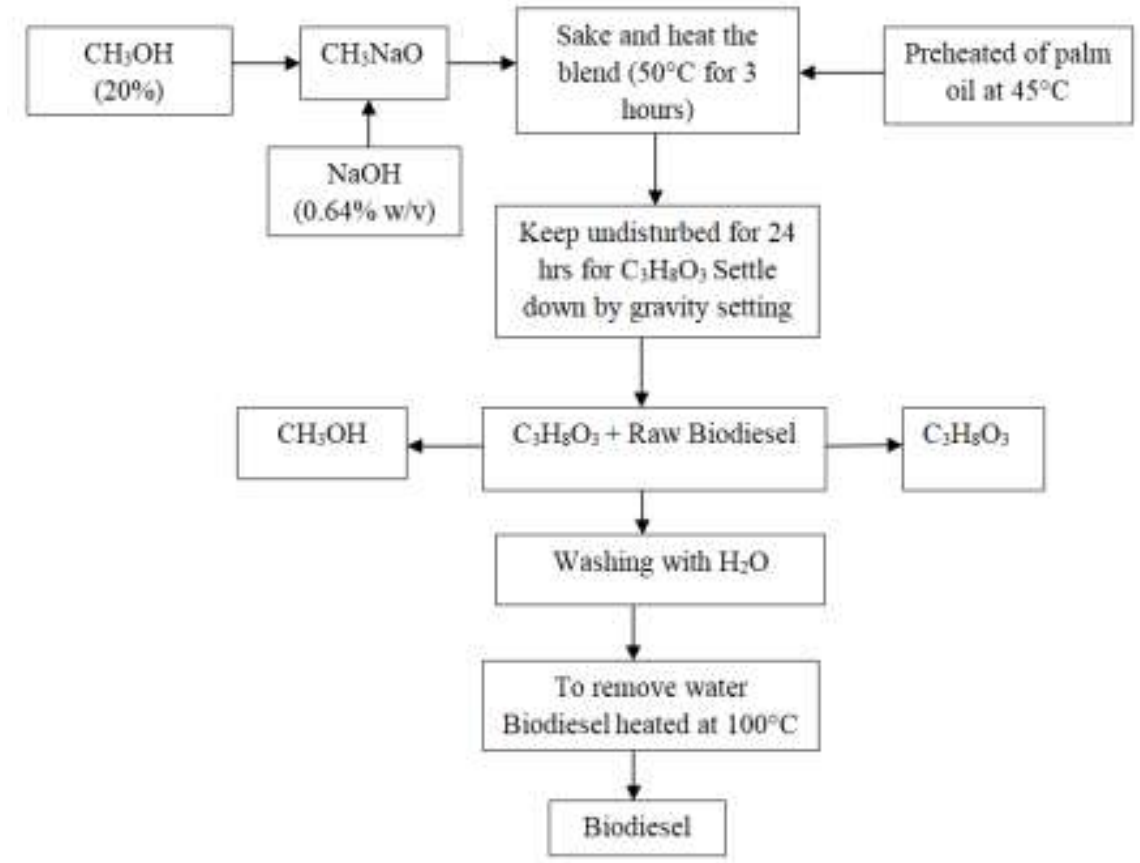

Figure 2. Steps involved during biodiesel production from palm oil [12]. 


\subsection{Blending (Alchol+Catalyst)}

During this process the sodium hydroxide $(0.8 \%$ of vegetable oil) is used as a catalyst and mixed with $\mathrm{CH}_{3} \mathrm{OH}$ (25\% of vegetable oil) properly.

\subsection{Reaction}

After blending the mixture is poured into a conical vessel and then heated palm oil $\left(45^{\circ} \mathrm{C}\right)$ is added and keeps the system in an air tight environment. Subsequently, on the water heater, the reaction take place at an isothermal temperature $\left(50^{\circ} \mathrm{C}-60^{\circ} \mathrm{C}\right)$ and reaction duration changes from one to eight hours.

\subsection{Separation}

During this step, glycerin (which is denser than biodiesel) is separated from biodiesel using gravity separation. Subsequently, vaporization is used to remove the remaining $\mathrm{CH}_{3} \mathrm{OH}$ which was still present in the biodiesel.

\section{4. Washing of methyl ester}

During this step washing is done 3 to 4 times to remove $\mathrm{CH}_{3} \mathrm{OH}$, residual free glycerine, catalyst and soap from obtaining biodiesel. Finally, pure biodiesel is obtained after heating of washed biodiesel at $100^{\circ} \mathrm{C}$ for a time period of 10 minutes to remove the water exist in the washed biodiesel. The Table 1 is illustrated below which indicates the name and chemical structures of common fatty acid found in palm oil.

Table 1: Composition of fatty acid observed in palm oil by wt. \% [11]

\begin{tabular}{|c|c|c|c|c|c|}
\hline S.NO. & Common Name & Chemical Name & Shorthand & $\begin{array}{c}\text { Molecular } \\
\text { Formula }\end{array}$ & \%age (By wt.) \\
\hline 1 & Lauric & Dodecanoic & $12: 0$ & $\mathrm{C}_{12} \mathrm{H}_{24} \mathrm{O}_{2}$ & 0.1 \\
\hline 2 & Myristic & Tetradecanoic & $14: 0$ & $\mathrm{C}_{14} \mathrm{H}_{28} \mathrm{O}_{2}$ & 0.7 \\
\hline 3 & Palmitic & Hexadecanoic & 16:0 & $\mathrm{C}_{16} \mathrm{H}_{32} \mathrm{O}_{2}$ & 36.7 \\
\hline 4 & Stearic & Octadecanoic & $18: 0$ & $\mathrm{C}_{18} \mathrm{H}_{36} \mathrm{O}_{2}$ & 6.6 \\
\hline 5 & Oleic & Cis-9-octadecenoic & $18: 1$ & $\mathrm{C}_{18} \mathrm{H}_{34} \mathrm{O}_{2}$ & 46.1 \\
\hline 6 & Linoleic & $\begin{array}{l}\text { Cis-9,Cis-12- } \\
\text { octadecadienoic }\end{array}$ & $18: 2$ & $\mathrm{C}_{18} \mathrm{H}_{32} \mathrm{O}_{2}$ & 8.6 \\
\hline 7 & Linolenic & $\begin{array}{c}\text { Cis-9, Cis-12,Cis-15- } \\
\text { octadecatrienoic }\end{array}$ & $18: 3$ & $\mathrm{C}_{18} \mathrm{H}_{30} \mathrm{O}_{2}$ & 0.3 \\
\hline
\end{tabular}

Palm oil is an effective and useful feedstock material for biodiesel production [13]. Currently, palm oil has become the $2^{\text {nd }}$ highest consumed feedsock material throughout the world with a less price in comparison with edible oils [14]. It is grown economically in South America, Africa, South Pacific, Southeast Asia and in other tropical areas [15].

\section{RESULT AND DISCUSSION}

\subsection{Production of biodiesel from palm oil by-products and mill effluent using Flask reactor.}

Various researchers produced biodiesel from from palm oil by-products and mill effluent using flask and batch reactor and give a different yield. Chongkhong, S. et al. [16] used palm fatty acid distillate as a raw material to produce (fatty acid methyl esters) FAME using a flask method in the presence of methanol and $\mathrm{H}_{2} \mathrm{SO}_{4}$ as catalyst. The reaction was carried out at a temperature b/w 343 to $353^{\circ} \mathrm{F}$ for 1.5 hours and gives $93.9 \%$ yield. 
Suwanno, S.et al. [17] produced biodiesel from palm oil mill effluent (POME) and palm fruit and catalyst gives yield $(92.07 \pm 1.04 \%)$ at $35^{\circ} \mathrm{C}$ using flask method. From the experimental result, it was noticed that $8 \%$ of oil was regained from palm oil mill effluent and produced biodiesel possess a high cetane number and cloud temperature (59-60) and $\left(10-13^{\circ} \mathrm{C}\right)$ respectively. Hindryawati, N. et al. [18] used ultrasound method to convert residual oil from palm decanter cake (PDC) into biodiesel. It was found that about $11.3 \mathrm{wt} \%$ of oil regained after 60 min. extraction. Aladetuyi, A. et al. [19] regained Palm kernel oil from spent bleaching earth and subsequently fresh oil was obtained from palm kernel gives a yield of $16 \%$ and $40.23 \%$ respectively using nhexane. After that trans-esterified process was used and the reaction takes place with methanol (oil $/ \mathrm{methanol:}$ $5: 1)$ at $373 \mathrm{~K}$ for $120 \mathrm{~min}$. The percentage yield obtained with cocoa pod ash catalyst was higher $(94 \%)$ than potassium hydroxide (90\%). Akinfalabi, S. et al. [20] used Palm fatty acid distillate to synthesis the biodiesel in the presence of a SPSC-SO ${ }_{3} \mathrm{H}$ catalyst. The result indicates that at $333.15 \mathrm{~K}$ biodiesel yield $97.8 \%$ during 120 minute reaction. Also, no treatment of catalyst needed up to eight esterification cycles and reused successfully. Surasit, C. et al. [21] applied tungstophosphoric acid to synthesis biodiesel from PFAD at $338.15 \mathrm{~K}$ for $28800 \mathrm{sec}$. About $90 \%$ yield of fatty acid methyl ester was obtained and properties of the biodiesel were as per the ASTM EN 14214 and D6751 standard. Astar, I. et al. [22] obtained the optimum conversion of methyl ester from sludge oil and crude palm oil in the presence of EFB ash \& alum catalyst and $86.17 \%$ yield was achieved. Manurung, R. et. al. [23] prepared biodiesel using sludge palm oil by esterification and transesterification reactions gives a yield of $83.19 \%$. Ricca, R.N. et al. [24] produced biodiesel using Sludge palm oil in the presence of enzymatic catalysis and gives a yield of $62.3 \%$. The result indicates that different alcohol, reaction temperature, alcohol to oil molar ratio, speed of mixing, enzyme loading and duration of the reaction, are the main parameters that influence the enzymatic biodiesel produced from sludge palm oil. Ngaini, Z. et al. [25] used palm oil mill sludge as a feedstock material and produced biodiesel in the presence of silica-based heterogeneous catalysts derived from Imperata cylindrica sp. The biodiesel was prepared using flask reactor, at $65^{\circ} \mathrm{C}$, for 1 hour gives yields of $80 \%$. The results of biodiesel production from Palm Oil by using Products with the help of Flask reactor are summarized in Table 2 and summarized graphically in Figure 3.

Table 2. Summary of biodiesel production from Palm Oil by using Products with the help of Flask Method.

\begin{tabular}{|c|c|c|c|c|c|c|c|c|}
\hline \multicolumn{9}{|c|}{ 1. Biodiesel Production Using Flask Method/Reactor. } \\
\hline $\begin{array}{c}\text { S } \\
\text { No } \\
\text {. }\end{array}$ & Year & Author & Raw Material & Catalyst & Alcohol & Time (s) & $\begin{array}{c}\text { Temp } \\
(\mathbf{K})\end{array}$ & Yield \% \\
\hline 1 & 2007 & Chongkhong, S. et al. [16] & PFAD & $\mathrm{H}_{2} \mathrm{SO}_{4}$ & $\mathrm{CH}_{3} \mathrm{OH}$ & 5400 & $\begin{array}{l}343.15- \\
353.15\end{array}$ & 93.9 \\
\hline 2 & 2017 & Suwanno, S. et al. [17] & POME & Crude lipase & $\mathrm{CH}_{3} \mathrm{OH}$ & 129600 & 308.15 & $\begin{array}{l}92.07 \\
\pm 1.04 \\
\end{array}$ \\
\hline 3 & 2017 & Hindryawati, N. et al. [18] & PDC & $\begin{array}{c}\text { Sulfonating rice } \\
\text { husk ash }\end{array}$ & $\mathrm{CH}_{3} \mathrm{OH}$ & 18000 & 393.15 & 70.2 \\
\hline \multirow{2}{*}{4} & \multirow{2}{*}{2014} & \multirow{2}{*}{ Aladetuyi, A. et al. [19] } & SBE & $\mathrm{CPA}$ & $\mathrm{CH}_{3} \mathrm{OH}$ & 7200 & 373.15 & 86.0 \\
\hline & & & SBE & $\mathrm{KOH}$ & $\mathrm{CH}_{3} \mathrm{OH}$ & 7200 & 373.15 & 81.2 \\
\hline 5 & 2017 & Akinfalabi, S. et al. [20] & PFAD & SPSC-SO ${ }_{3} \mathrm{H}$ & $\mathrm{CH}_{3} \mathrm{OH}$ & 7200 & 333.15 & 97.8 \\
\hline 6 & 2017 & Surasit, C. et al. [21] & PFAD & $\mathrm{TPA} / \mathrm{Cs} 1.0 / \mathrm{Nb}^{2} \mathrm{O}_{5}$ & $\mathrm{CH}_{3} \mathrm{OH}$ & 28800 & 338.15 & 90 \\
\hline 7 & 2017 & Astar, I. et al. [22] & SO & EFB ash \& Alum & $\mathrm{CH}_{3} \mathrm{OH}$ & 10800 & 338.15 & 86.17 \\
\hline 8 & 2017 & Manurung, R. et. al. [23] & SO & $\begin{array}{l}\mathrm{NaOH} \& \text { Deep } \\
\text { eutectic solvent }\end{array}$ & NIL & 3600 & 353.15 & 83.19 \\
\hline 9 & 2013 & Ricca, R.N. et al. [24] & SO & C. cylindracea lipase & $\mathrm{C}_{2} \mathrm{H}_{5} \mathrm{OH}$ & 86400 & 313.15 & 62.3 \\
\hline 10 & 2016 & Ngaini, Z. et al. [25] & SO & $\begin{array}{c}\text { Imperata cylindrica } \\
\text { sp. }\end{array}$ & $\mathrm{CH}_{3} \mathrm{OH}$ & 3600 & 338.15 & 80 \\
\hline
\end{tabular}

Abbreviations: (PFAD- Palm Fatty Acid Distillate), (SO- Sludge Oil), (PDC- Residual oil from palm ecanter cake), (SBE- Residual oil of spent bleaching earth), (POME- Residual from Palm oil mill effluent), (CPA- 
Cocoa pod ash), (KOH- potassium hydroxide), (SPSC-SO $\mathrm{S}_{3} \mathrm{H}$-sulfonated soaked palm seed cake), (TPA/Cs1.0/ $\mathrm{Nb}_{2} \mathrm{O}_{5}$ - tungstophosphoric acid), $\left(\mathrm{CH}_{3} \mathrm{OH}-\mathrm{Methanol}\right),\left(\mathrm{H}_{2} \mathrm{SO}_{4-}\right.$ Sulphuric acid)

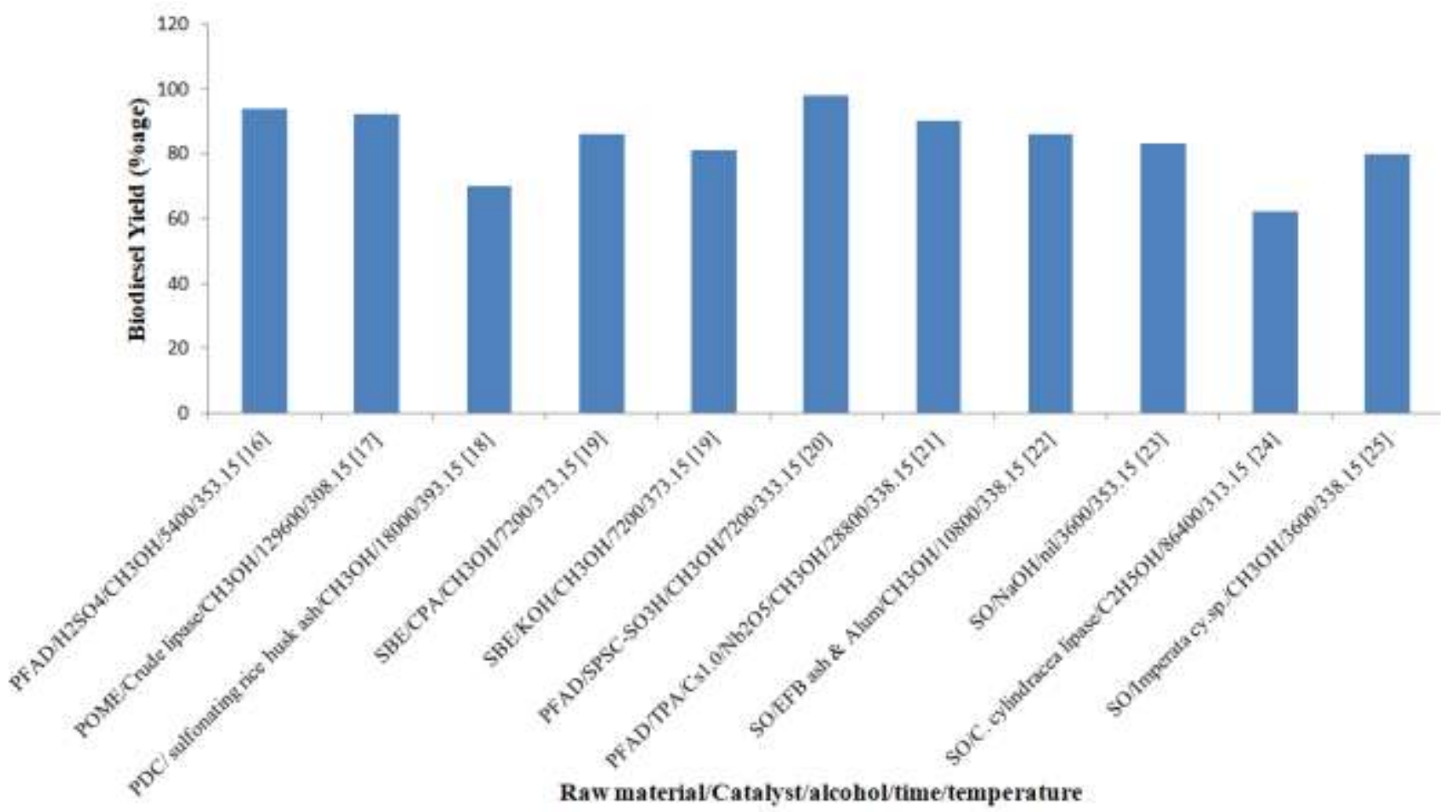

Figure 3. Biodiesel yield \% age vs. raw material/catalyst/alcohol/time (s) /temperature (K) by using Flask reactor.

\subsection{Production of Biodiesel from palm oil by products and mill effluent using batch reactor.}

Aranda, D.A.G. et al. [26] investigated the esterification of palm fatty acid to prepare biodiesel in the presence of different catalysts. The author studied the influence of alcohol used, presence of $\mathrm{H}_{2} \mathrm{O}$, concentration of catalyst, and type of catalysts on biodiesel yield. The author reported that $\mathrm{H}_{2} \mathrm{SO}_{4}$ and $\mathrm{CH}_{4} \mathrm{O}_{3} \mathrm{~S}$ were the best catalysts. The presence of $\mathrm{H}_{2} \mathrm{O}$ in the reaction medium represented a adverse consequences in the reaction velocity whereas, reaction with $\mathrm{CH}_{3} \mathrm{OH}$ gives more yields. Baroutian, S. et al. [27] carried out transesterification of refined, deodorized and bleached palm olein with $\mathrm{CH}_{3} \mathrm{OH}, \mathrm{C}_{2} \mathrm{H}_{5} \mathrm{OH}$ and their blends at different $\mathrm{CH}_{3} \mathrm{OH} / \mathrm{C}_{2} \mathrm{H}_{5} \mathrm{OH}$ ratio and molar ratio of $1 / 6$ in the existance of $\mathrm{KOH}$. The author attained 98.10\% biodiesel yield when using $\mathrm{CH}_{3} \mathrm{OH} / \mathrm{C}_{2} \mathrm{H}_{5} \mathrm{OH}$ ratio of 4:2 and molar ratio of alcohol to oil was 6:1, a reaction duration of 60 minutes, at $50^{\circ} \mathrm{C}$. Sakdasri, W. et al. [28] produced biodiesel at low $\mathrm{CH}_{3} \mathrm{OH} / \mathrm{oil} \mathrm{molar}$ ratio (12:1) from used and refined palm olein oil. The author concluded that the used palm olein oil with more FFA (4.56 wt. \%) can be used as a feedstock material for biodiesel production that gives a higher ester content of eighty percent. Also, the side reaction between $\mathrm{C}_{3} \mathrm{H}_{8} \mathrm{O}_{3}$ and $\mathrm{CH}_{3} \mathrm{OH}$ at $673.15 \mathrm{~K}$ and $15 \times 10^{6} \mathrm{~N} / \mathrm{m}^{2}$ represented a positive influence in increasing fuel yield by $2 \%$ to $7 \%$. Suryani, A. et al. [29] produced biodiesel from residual oil of spent bleaching earth in a 100 liter batch reactor at the different transesterification time $(60,90$ and 120 minutes), and stirring speeds $(650 \mathrm{rpm}$ and $730 \mathrm{rpm})$. The result showed that at $730 \mathrm{rpm}$ and 90 minutes transesterification time gives best result with the yield of $85 \%$. Klabsong, M. et al. [30] evaluated the parameters of residual oil and observed $3.767 \%$ wt FAME, $22.03 \%$ wt of FFA, acid value of $49.29 \mathrm{mg} \mathrm{KOH} / \mathrm{g}$, a $\mathrm{H}_{2} \mathrm{O}$ content of $1.01 \% \mathrm{mg} / \mathrm{Kg}$, total glycerines as triglyceride, diglycerides and monoglycerides at $87.54 \%$ $\mathrm{m} / \mathrm{m}, 11.88 \% \mathrm{~m} / \mathrm{m}$ and $1.15 \% \mathrm{~m} / \mathrm{m}$ respectively. The results of biodiesel production using Palm Oil by using Products with the help of Batch reactor are summarized in Table 3 and summarized graphically in Fig. 4. 
Table 3. Summary of biodiesel production from Palm Oil by using Products with the help of Batch Method or Reactor.

\begin{tabular}{|c|c|c|c|c|c|c|c|c|}
\hline \multicolumn{9}{|c|}{ 2. Biodiesel Production Using Batch Reactor } \\
\hline $\begin{array}{c}\text { S } \\
\text { No. }\end{array}$ & Year & Author & Raw Material & Catalyst & Alcohol & $\begin{array}{c}\text { Time } \\
(\mathrm{s})\end{array}$ & $\begin{array}{c}\text { Temp } \\
(\mathbf{K})\end{array}$ & Yield \% \\
\hline 1 & 2008 & Aranda, D.A.G. et al. [26] & FAR & $\mathrm{H}_{2} \mathrm{SO} 4$ & $\mathrm{C}_{2} \mathrm{H}_{5} \mathrm{OH}$ & 3600 & 403.15 & $>90.0$ \\
\hline 2 & 2009 & Baroutian, S. et al. [27] & UPO & $\mathrm{KOH}$ & $\mathrm{CH}_{3} \mathrm{OH} / \mathrm{C}_{2} \mathrm{H}_{5} \mathrm{OH}(4: 2)$ & 3600 & 323.15 & 98.1 \\
\hline 3 & 2015 & Sakdasri, W. et al. [28] & $\mathrm{PO}$ & $\mathrm{KOH}$ & $\mathrm{CH}_{3} \mathrm{OH} / \mathrm{C}_{2} \mathrm{H}_{5} \mathrm{OH}$ & 3600 & 323.15 & 98.1 \\
\hline 4 & 2017 & Suryani, A. et al. [29] & SBE & $\mathrm{H}_{2} \mathrm{SO}_{4} \& \mathrm{NaOH}$ & $\mathrm{CH}_{3} \mathrm{OH}$ & 5400 & 338.15 & 85 \\
\hline 5 & 2017 & Klabsong, M. et al. [30] & POME & Non- Catalytic & $\mathrm{CH}_{3} \mathrm{OH}$ & 18000 & 503.15 & 77.64 \\
\hline
\end{tabular}

Abbreviations: (FAR-Fatty acid residue), (FAC- Fatty Acid Residue), (UPO- Used Palm Olein/Glycerol), (POPalm Olein), (SBE-Residual oil of spent bleaching earth), (POME- Residual from Palm oil mill effluent), $\left(\mathrm{C}_{2} \mathrm{H}_{5} \mathrm{OH}-\right.$ Ethanol).

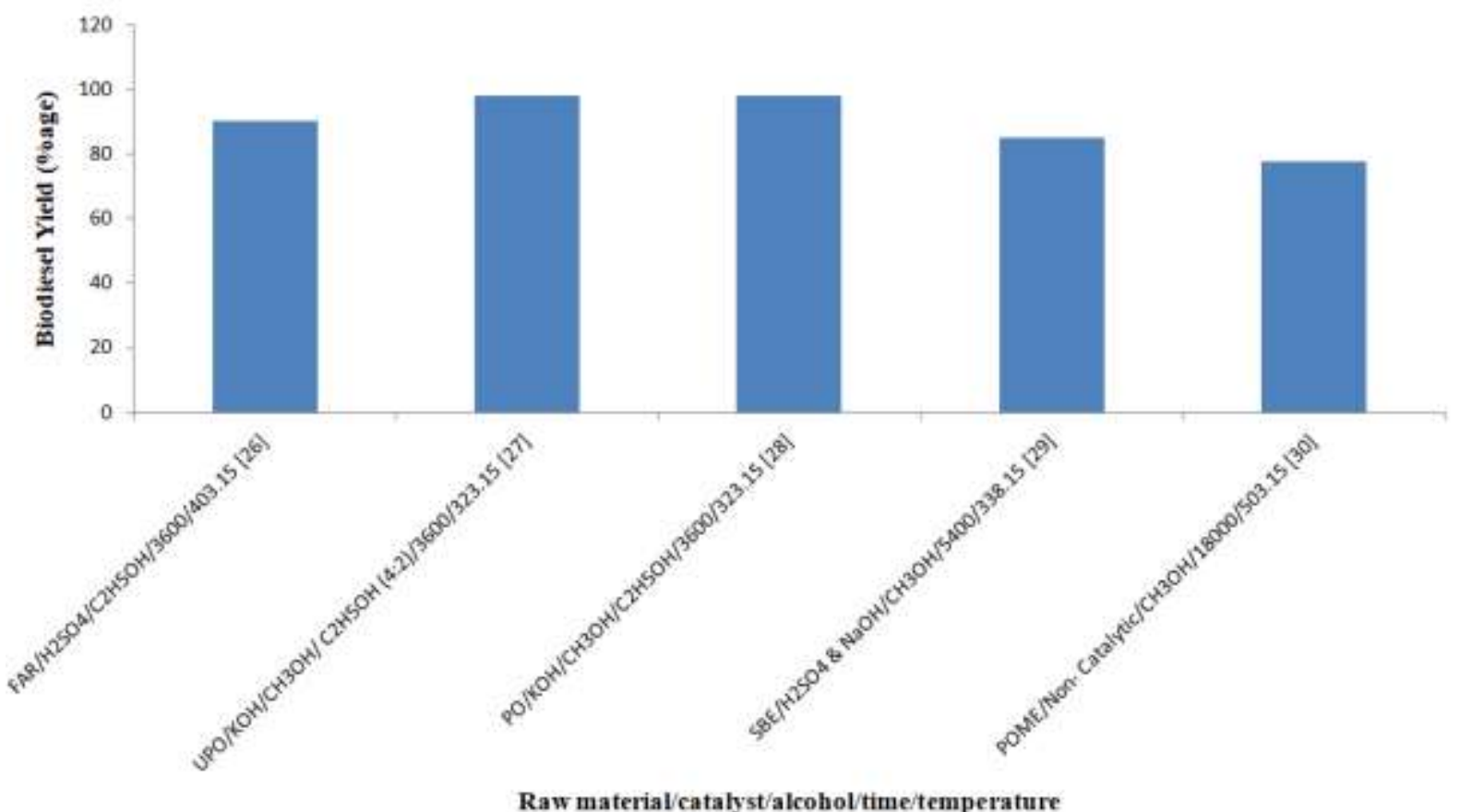

Figure 4. Biodiesel yield \%age vs. raw material/catalyst/alcohol/time (s) /temperature (K) by using Batch reactor.

\section{CONCLUSIONS}

Due to increasing the number of vehicles, energy demand is also increasing which result in depletion of fossil resources. Hence effort must be applied to search inexhaustable and eco friendly energy sources (vegetable oils/animal fats). Palm oil by-products and mill effluent is one of the best low cost alternative and renewable feedstock material for biodiesel production because of its attractive properties such as easily available, environment-friendly, techno-economically competitive as well as less impact on food security. Further, it has been concluded that Palm fatty acid distillate and refined bleached and deodorized palm olein offered a very high yield, i.e. $97.8 \%$ and $98.1 \%$ using flask and batch reactor respectively. Hence a comprehensive study is still needed. 


\section{References}

[1] Islam, M. A., Hasanuzzaman, M. and Rahim, N. A. (2014), "Global renewable energy-based electricity generation and smart grid system for energy security", Scientific World Journal, 1, 1-10.

[2] Kumar, R., Kumar, S. \& Chawla, V. (2017), "Application of biodiesel produced from argemone mexicana oil in direct injection compression ignition engine", International Journal of Latest Trends In Engineering And Technology, 2, 305-312.

[3] Kumar, R., and Kumar S., (2017), "Impact of eucalyptus oil and diesel mixture on engine performance in a four stroke single cylinder engine operation", International Journal for Scientific Research \& Development, 5 (3), 2288-2293.

[4] Kumar, S., Chandel, R., and Kumar, R., (2016), "Performance and emission characteristics of eucalyptus oil and diesel blend in four stroke single cylinder diesel engine" International Journal of Engineering Sciences and Research Technology, 5 (2), $710-720$.

[5] Chandel, R., Kumar, S. and Kumar, R., (2016), "Performance and emission characteristics in a diesel engine using cotton seed oil and diesel blend" International Journal of Enhanced Research in Science Technology and Engineering, 5 (2), 78-88.

[6] Venkatesan, M., Vikram, C.J. and Naveenchandran, P. (2012), "Performance and emission analysis of pongamia oil methyl ester with diesel blend", Journal of Science \& Research, 12, 1758-1765.

[7] Solanki, D. and Agarwal, A. (2012) "Vegetable to study of vegetable oils and their effects on diesel engine performance", International Journal of Scientific and Research, 10, 71-89.

[8] Adewale, P., Dumont, M.J. and Ngadi, M. .(2015), "Recent trends of biodiesel production from animal fat wastes and associated production techniques", Renew. Sustain. Energy rev, 45, 574-588.

[9] Fangrui, M., and Milford A. (1999), "Biodiesel production: a review”, Bioresource Technology, 70, 1-15.

[10] Nabel A., Kana, A. and Mona A. (2001), "Biofuels from vegetable oils as alternative fuels advantages and disadvantages", Surfactants in Tribology, 5, 289-367. DOI: 10.1201/9781315120829-18.

[11] Ramos, M., Fernández, C.Z., "Influence of fatty acid composition of raw materials on biodiesel properties", Journal of Bioresource Technology, 100 (1), 261-268.

[12] Mamun, A.A., Siddiqua, S. and Babar, S. (2013), "Selection of an efficient method of biodiesel production from vegetable oil based on fuel properties", International Journal Of Trends and Technology, 4(8), 3289-3293.

[13] Yean, G.P. and Dong, L. Z. (2012), “A study on Malaysia’s palm oil position in the world market to 2035, IEEEJ, 1-4.

[14] Bazlul, M., Ibrahim, M.H. and Hena, S. (2010), "Physico chemical properties of blends of palm olein with other vegetable oils," Grasas Y Aceites. Octubrediciembre, 61 (4), 423-429.

[15] Sheil, D., Casson, A., Meijaard, E., Van Nordwijk, M. Gaskell, J., Sunderland-Groves, J., Wertz, K. and Kanninen, M. (2009), "The impacts and opportunities of oil palm in Southeast Asia: What do we know and what do we need to know", Occasional paper no. 51. CIFOR, Bogor, Indonesia.

[16] Chongkhong, S., Tongurai, C., Chetpattananondh, P. and Bunyakan, C. (2007), "Biodiesel production by esterification of palm fatty acid distillate", Biomass Bio energy, 31, 563-568.

[17] Suwanno, S., Rakkan, T., Yunu, T., Paichid, N. and Kimtun, P. (2017), "The Production of biodiesel using residual oil from palm oil mill effluent and crude lipase from oil palm fruit as an alternative substrate and catalyst," Fuel, 195, 82-87.

[18] Hindryawati, N.E and Maniam, G.P. (2017), "Esterification of oil adsorbed on palm decanter cake into methyl ester using sulfonated rice husk ash as heterogeneous acid catalyst”, AIP Conf. Proc. 2017, 1813, 1-11.

[19] Aladetuyi, A., Olatunji, G., Ogunniyi, D.S., Odetoye, T.E. and Oguntoye, S.O. (2014), "Production and characterization of biodiesel using palm kernel oil; fresh and recovered from spent bleaching earth", Journal of Biofuel Resources, 4, 134-138.

[20] Akinfalabi, S.I., Rashid, U., Yunus, R. and Taufiq-Yap, Y.H. (2017), "Synthesis of biodiesel from palm fatty acid distillate using sulfonated palm seed cake catalyst", Renew. Energy, 111, 611-619.

[21] Surasit, C., Yoosuk, B. and Pohmakotr, M. (2017), "Biodiesel synthesis from palm fatty acid distillate using tungstophosphoric acid supported on cesium-Containing niobia”, Journal of Am. Oil Chem. Soc., 94, 465-474.

[22] Astar, I., Usman, T., Wahyuni, N., Rudiyansyah and Alimuddin, A.H. (2017), "Bifunctional heterogeneous catalysts from oil palm empty fruit bunches ash and alum for biodiesel synthesis simultaneously", AIP Conf. Proc., 1823, 1-6.

[23] Manurung, R., Ramadhani, D.A. and Maisarah, S. (2017), "One step transesterification process of sludge palm oil (SPO) by using deep eutectic solvent (DES) in biodiesel production”, AIP Conf. Proc., 1855, 1-9. 
[24] Ricca, R.N., Md, Z.A. and Mohammed, S.J.(2013), "Enzymatic biodiesel production from sludge palm oil (SPO) using locally produced Candida cylindracea lipase”, Afr. J. Biotechnol., 12, 4966-4974.

[25] Ngaini, Z., Shahrom, F.D., Jamil, N., Wahi, R. and Ahmad, Z.A. (2016), "Imperata cylindrica sp as novel silica-based heterogeneous catalysts for transesterification of palm oil mill sludge”, Journal of Oleo Science, 65,507-515.

[26] Aranda, D.A.G.; Santos, R.T.P.; Tapanes, N.C.O.; Ramos, A.L.D.; Antunes, O.A.C. Acid-catalyzed homogeneous esterification reaction for biodiesel production from palm fatty acids. Catal. Lett. 2008, 122, 20-25.

[27] Baroutian, S., Aroua, M.K., Raman, A.A. and Sulaiman, N.M. (2009), "RBD palm olein-based methyl/ethyl esters, Journal of Oil Palm Research, 2009, 21, 659-666.

[28] Sakdasri, W., Sawangkeaw, R., and Ngamprasertsith, S. (2015), "Continuous production of biofuel from refined and used palm olein oil with supercritical methanol at a low molar ratio", Energy Convers. Manag. 103, 934-942.

[29] Suryani, A., Mubarok, Z., Suprihatin, Romli, M. and Yunira, E.N (2017), "Process design of in situ esterificationTransesterification for biodiesel production from residual oil of spent bleaching earth (SBE)", IOP Conf. Ser. Earth Environ. Sci., 65, 1-11.

[30] Klabsong, M., Kungskulniti, N. and Puemchalad, C (2017), "Feasibility study of biodiesel production from residual oil of palm oil mill effluent", Int. J. GEOMATE, 12, 60-64. 